\title{
Digestive System Neuroendocrine Tumor TNM Finding v8
}

National Cancer Institute

\section{Source}

National Cancer Institute. Digestive System Neuroendocrine Tumor TNM Finding v8. NCI Thesaurus. Code C135019.

A finding about one or more characteristics of a digestive system neuroendocrine tumor, following the rules of the TNM AJCC v8 classification system. 